\title{
杭基礎の杭頭結合部における応力分布について STRESS DISTRIBUTION ON THE CONNECTION BETWEEN PILE-HEAD AND FOOTING OF PILE FOUNDATION
}

\author{
小堀為雄* ·近田康夫** \\ By Tameo KOBORI and Yasuo CHIKATA
}

\begin{abstract}
In this paper, it is investigated that how axial load and buried length of pile-head into footing under lateral load effect on the stress distribution of footing concrete on pilefooting interface. For the evaluation of the effects, the connection between pile-head and footing is treated as an axisymmetric body subjected to non-axisymmetric loading, and the evaluation is performed by Finite Element Analysis. For the analysis, it is assumed that debonding or slip never occur on the interface.

The results suggest that axial load and buried pile-head length have significant effects on the stress distribution, and the cohesion on the interface is very significant factor on the stress distribution.
\end{abstract}

\section{1. 緒言}

構造物を構成する個々の要素をつなぐ結合部は，構造 物の安全性を検討するうえできわめて重要な位置を占め ると考えられるが, 杭頭部とフーチングの結合部の安全 性や設計方法の妥当性の検討は, はり一柱結合部等のそ れに比較して立ち遅れの観があるように思われる.

現行の道路橋示方書 ${ }^{1)}$ には, 杭頭とフーチングの結合 部の設計に関して，2つの方法が規定されている.この $2 つ$ つ結合方法は, 建設省土木研究所が, 杭頭結合部に 関する設計例や実験・試験例を収集・分析の結果提案し た 1 つのスタンダードであり, 昭和 47 年に道路局企画 課長通達として行政的措置がなされて今日に至ってい る2).

この 2 つ結合方法は, いずれも杭頭部をフーチング に䍑結するもので, その概略図および応力照査のための 応力分布の仮定, 応力照查式は図一1 の上うに示される. 示方書では，鋼管杭，PC 杭，場所打ち杭に対しておの おの構造細目を示しているが, 図一1はPC 杭に対する ものの概略図である. 図において, 方法 A は, フーチ

\footnotetext{
* 正会員 工博 金沢大学教授 工学部建設工学科 （解920 金沢市小立野 2-40-20）

** 正会員 工修 金沢大学助手 工学部建設工学科 (同上)
}

ング内に杭を杭径以上埋め込み, 埋込み部をもって杭頭 拘束モーメントに抵抗させる方法であり, 方法 B は,

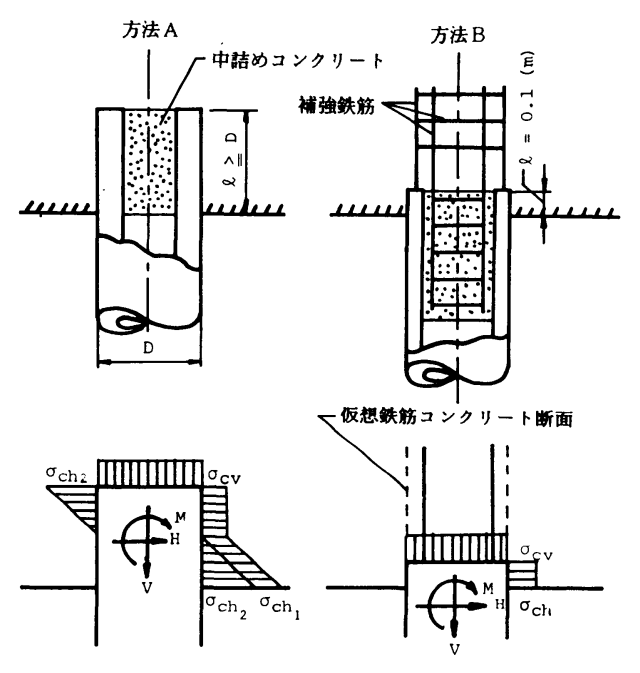

$$
\begin{aligned}
& \sigma_{\mathrm{cV}}=\frac{4 \mathrm{~V}}{\pi \mathrm{D}^{2}} \leq \sigma_{\mathrm{ca}} \quad \sigma \mathrm{cv}=\frac{4 \mathrm{~V}}{\pi \mathrm{D}^{2}} \leq \sigma_{\mathrm{ca}} \\
& \sigma c h=\sigma c h_{1}+\sigma c h_{2} \leqq \sigma c a \quad \sigma c h=\frac{H}{D l} \leqq \sigma c a \\
& \sigma c h_{1}=\frac{H}{D l}, \sigma c h_{2}=\frac{6 M}{D l^{2}} \quad \sigma c a: \text { 竍容応力度 }
\end{aligned}
$$

図一1 PC 杭の杭頭結合部および㐫力照査のための 応力分布の仮定, 応力照査式 
フーチング内に, 杭径にかかわらず $10 \mathrm{~cm}$ だけ杭を埋 め込み，杭頭に設けた補強鉄筋により杭頭拘束モーメン トに抵抗させる方法である.鋼管杭では, 中詰めコンク リートの代わりに鋼製蓋板を取り付け, RC 杭では $\mathrm{PC}$ 杭に準ずる.また，場所打ち杭では，方法 B のみを用 いるとされている.

これらの結合方法は, 収集した設計例等の机上検討の 結果, 標準的な設計方法として提案されたものであった ことから, 上記通達以後, 今日まで, 主に実験を通して その安全性や妥当性に対する検討が加えられてきだ!

それらの実験は,ほとんどが,鉄筋コンクリート製フー チングに単杭を結合した模型を用い，杭先端に軸力や水 平力を作用させて, 軸力, 杭頭埋込み長, 杭とフーチン グの間の付着, 中詰めコンクリート, 補強鉄筋, 蓋板等 の影響から, 杭頭結合部の強度, 固定度, 応力分布の仮 定の妥当性等を検討している.

上記の実験報告では, 実際に杭頭結合部のフーチング コンクリートに生ずる支圧応力は, 応力の分散や杭と フーチングの間の付着の影響から，示方書の応力照査式 より算出される值に比較してかなり小さい. また，結合 部の破壊強度は計算值の約 $2.5 \sim 3.0$ 倍である. 方法 $\mathrm{B}$ が方法 A に比較してやや劣るとはいえ，ほぼ完全剛結 の条件を満足している等の点を指摘している. 一方，一 部では,やや過剩設計となっているのでは，との指摘も ある．また，最近では，設計方法の簡素化を指向した夹 験的研究 ${ }^{4)}$ みられる. しかし，より合理的な設計方法 を提示するにはいまだ不明な点が多いとされている.

このような, 設計方法の模索ともいえる研究において は，実験的検討とともに，数值計算によるパラメトリッ ク・スタディが有効な手段であると思われるが, わずか に有限要素法を用いた解析例 ${ }^{5), 6)}$ が散見されるのみであ り, 杭頭結合部の構造的重要性を考えれば,この方面の 研究の意義は大きいと考えられる.

本研究では, 以上の背景のもとに, 構造物における一 結合構造としての杭頭結合部に着目し, 杭頭結合部の応 力状態に影響を及ぼす種々の因子のうち, 軸力と杭頭埋 込み長の 2 因子の影響を, 有限要素法を用いた弾性線形 解析により検討を行い, 今後の解析および設計の資料と したい.

\section{2. 解析手法}

杭頭結合部は, 形状的には軸対称構造としてモデル化 できるが，一般に荷重条件は軸対称ではないので，厳密 には三次元解析が必要である.上述の解析例 ${ }^{5), 6)}$ が, 軸 力のみを作用させた軸対称問題にとどめている理由の 1 つはこのことであろう. しかし，以下に示す半解析的手 法を用いれば, 擬似二次元解析が可能である71. 黒正ら ${ }^{81}$
もこの手法を用いて，実験結果との比較を行っており， この手法が有効であることを示している．以下では，文 献 ${ }^{9)}$ に従って,「非軸対称荷重を受ける軸対称体」の弾 性線形有限要素解析手法について概述する.

座標系は三次元の円筒座標系 $(r, z, \theta)$ を用いる. $r, z, \theta$ 方向の変位および荷重をそれぞれ $u, v, w$ およ び $f_{r}, f_{z}, f_{\theta}$ とし, おのおの $\theta$ 方向にフーリエ級数展開 すれば，第 $m$ 調和成分まで採用して次式のように表わ せる.

$$
\begin{aligned}
& u=N(r, z)\left\{\delta_{0}+\sum_{n=1}^{m} \bar{\delta}_{n} \cos n \theta+\sum_{n=1}^{m} \bar{\delta}_{n} \sin n \theta\right\} \cdots(1) \\
& \boldsymbol{f}=\boldsymbol{f}_{0}+\sum_{n=1}^{m} \overline{\boldsymbol{f}}_{n} \cos n \theta+\sum_{n=1}^{m} \overline{\bar{f}}_{n} \sin n \theta \\
& \boldsymbol{u}=\{u, v, w\}^{T} \\
& \boldsymbol{f}=\left\{f_{r}, f_{z}, f_{\theta}\right\}^{T}
\end{aligned}
$$

ただし，式（1)中， $\boldsymbol{\delta}$ は節点変位ベクトルを， $N$ は形 状関数行列を表わす， $m$ は荷重が十分な精度で表現で きる項数である.

円筒座標系における変位-ひずみ関数式は,

$$
\varepsilon=\left\{\begin{array}{c}
\varepsilon_{r} \\
\varepsilon_{z} \\
\varepsilon_{\theta} \\
\gamma_{r z} \\
\gamma_{r \theta} \\
\gamma_{z \theta}
\end{array} \mid=\left\{\begin{array}{l}
\frac{\partial u}{\partial r} \\
\frac{\partial v}{\partial z} \\
\frac{u}{r}+\frac{1}{r} \cdot \frac{\partial w}{\partial \theta} \\
\frac{\partial u}{\partial z}+\frac{\partial v}{\partial r} \\
\frac{\partial w}{\partial r}+\frac{1}{r}\left(\frac{\partial u}{\partial \theta}-w\right) \\
\frac{\partial w}{\partial z}+\frac{1}{r} \cdot \frac{\partial v}{\partial \theta}
\end{array}\right\}\right.
$$

式（1），（3)，（5）より節点変位-ひずみ関係式は,

$$
\varepsilon=B \delta=\left\{B^{0} B^{1} \cdots B^{m}\right\}\left\{\delta_{0} \delta_{1} \cdots \delta_{m}\right\}^{T}
$$$$
\delta_{n}=\left\{\bar{\delta}_{n} \overline{\bar{\delta}}_{n}\right\}^{T} \quad(n \geqq 1)
$$

となる. 節点 $i$ に対するひずみマトリックス $\boldsymbol{B}_{i}^{n}$ は,

$$
\boldsymbol{B}_{i}^{n}=\left\{\bar{B}_{i}^{n} \overline{\boldsymbol{B}}_{i}^{n}\right\} \quad(n \geqq 1)
$$$$
\overline{\boldsymbol{B}}_{i}^{n}=\boldsymbol{B}_{i}^{0} \cos n \theta-\hat{\boldsymbol{B}}_{i} \sin n \theta
$$$$
\bar{B}_{i}^{n}=B_{i}^{0} \sin n \theta+\hat{B}_{i} \cos n \theta
$$

となる. 上式中, $\boldsymbol{B}_{i}^{0}, \hat{B}_{i}$ は次式のようである.

$$
\boldsymbol{B}_{i}^{0}=\left[\begin{array}{ccc}
\frac{\partial N_{i}}{\partial r} & 0 & 0 \\
0 & \frac{\partial N_{i}}{\partial z} & 0 \\
\frac{N_{i}}{r} & 0 & 0 \\
\frac{\partial N_{i}}{\partial z} & \frac{\partial N_{i}}{\partial r} & 0 \\
0 & 0 & \frac{\partial N_{i}}{\partial r}-\frac{N_{i}}{r} \\
0 & 0 & \frac{\partial N_{i}}{\partial z}
\end{array}\right],
$$




$$
\hat{\boldsymbol{B}}_{i}=\frac{n N_{i}}{r}\left[\begin{array}{ccc}
0 & 0 & 0 \\
0 & 0 & 0 \\
0 & 0 & 1 \\
0 & 0 & 0 \\
1 & 0 & 0 \\
0 & 1 & 0
\end{array}\right]
$$

ただし， $N_{i}$ は $N$ の節点 $i$ に関する成分である.

一般に要素剛性マトリックスの部分マトリックスは, $\boldsymbol{D}$ を弾性マトリックスとして, 次式のように表わせる.

$$
\begin{aligned}
& \boldsymbol{K}_{i j}^{l n}=\int\left(\boldsymbol{B}_{i}^{l}\right)^{T} \boldsymbol{D} \boldsymbol{B}_{j}^{n} d(v o l) \quad(l, n=1,2, \cdots) \\
& \text { ところが, 三角関数の直交性から }
\end{aligned}
$$

$$
\boldsymbol{K}_{i j}^{l n}=0 \quad(l=n)
$$

となり, 結局, 要素ごとに重ね合わせた全体のつり合い 式は, 調和成分ごとに, $m+1$ 組のフーリエ係数に関す る連立方程式に分離することができ，次式のように表わ すことができる.

$$
\begin{aligned}
& \left.\left[\begin{array}{ccc}
K^{00} & & \\
& & 0 \\
0 & K^{n n} & \\
& & K^{m m}
\end{array}\right] \mid \begin{array}{l}
\delta^{0} \\
\delta^{n} \\
\delta^{m}
\end{array}\right)=\left(\begin{array}{l}
f^{0} \\
f^{n} \\
f^{m}
\end{array}\right) \\
& \delta^{n}=\left\{\delta_{1}^{n} \delta_{2}^{n} \cdots \delta_{K}^{n}\right\}^{T} \\
& f^{n}=\left\{f_{1}^{n} f_{2}^{n} \cdots f_{K}^{n}\right\}^{T}, K \text { : 節点数 }
\end{aligned}
$$

式(14) を解いて $\delta$ を求めた後, 式 (1) 等によりフー リ工級数の合成を行えば，変位，ひずみ，応力等が算出 でき，おのおのの $\theta$ の值に対して同様にすれば, 三次元 解が得られる.なお, 0 次調和成分については, 普通の 軸対称問題を解くことになる.

文献 ${ }^{9)}$ は述べられていないが，本手法により，杭頭 結合部のような中実軸対称体を解析する場合, $r=0$, す なわち, 回転軸における境界条件に注意する必要があり, それらは次式で示される ${ }^{10)}$.

$$
\begin{array}{ll}
u=w=0 & (n=0) \\
u+w=0, \quad v=0 & (n=1) \\
u=v=w=0 & (n \geqq 2)
\end{array}
$$

なお，次章で述べる解析結果では，式(14)を解く場合 に，共役傾斜法を用い，方程式のスケーリングを行うこ とにより解の収束を速めている.

\section{3. 解析およびその考察}

本章では，前章で述べた手法を用いた杭頭結合部の解 析結果およびその考察を述べる.

杭頭結合部は，図一2に示すように軸対称体としてモ デル化する．ここでは，無筋のコンクリート製フーチン グに高剛性コンクリート杭（PC 杭を杭の剛性のみで表 現したと考える）を結合し，モデルの制約上，荷重を杭 先端に加える場合を考える.

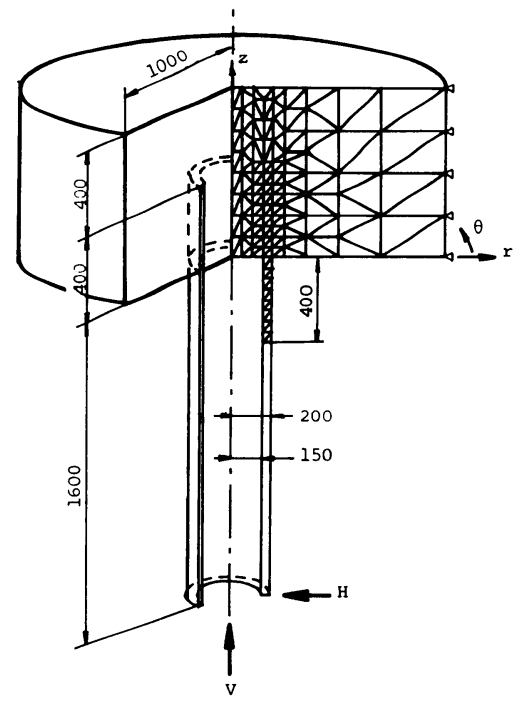

図一2＼cjkstart杭頭結合部解析モデルおよび有限要来分割

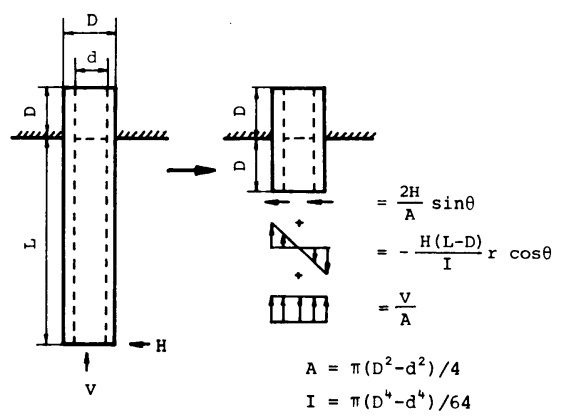

図一3 荷重の韯荷方法

構造は, 弾性結合された片持ちばりと考えることがで きるが，はり部分については本来の解析目的ではなく， また，水平力をフーリ工級数展開した場合の採用次数が 多くなることを考慮して，ここでは，杭の張り出し長を 杭径に等しくとり, その先端に, 軸力および水平力と等 価な断面力を作用させる (図一3参照).これにより， 解析は, フーリエ級数の 0 次および一次の調和成分につ いてだけ行えばよいことになる.

また，杭頭とフーチングとの間の境界面は連続とし， 境界面において㔀離やすべりが発生する以前を解析対象 とする。

有限要素としては 3 節点三角形断面リング要素を用 い, 要素分割は, 図一2 の切断面に示すとおりである.

解析は, 杭に作用する軸力 $V$ および杭頭部のフーチ ングへの埋込み長 $l$ が杭頭結合部の応力状態に及ぼす影 響をみるために，表一1 に示すように， $V=-5.00,0.0$ ， $5.00,10.00 \mathrm{tf}(-49,0,49,98 \mathrm{kN})$ の 4 通り, $l=0.4$, $0.2,0.1 \mathrm{~m}$ （杭径 $D$ との比で $l / D=1.00,0.50,0.25$ ) 
の 3 通り，の計 12 通りの計算を行った。なお，いずれ の計算においても, 水平力 $1.0 \mathrm{tf}(9.8 \mathrm{kN})$ を作用させ ている. $l=0.4 \mathrm{~m}(l / D=1.0)$ は，示方書における方 法 A に相当し, $l=0.1 \mathrm{~m}$ は方法 B（ただし, 補強鉄筋 およびフーチング下面以下の中詰めコンクリートはな い）に相当すると考えてよい.

解析結果を $l / D$ の値によって, 図一4 図一6の3つ に分けて示す, すなわち, 図一4, 図一5, 図一6には, それぞれ，表一1中の Run No. 1〜4，5〜8，9〜12の 各解析結果を示してある. 各図では, $(\mathrm{a})$ （b) に杭頭 部外側面 $(r=D / 2)$ の境界面を軸にとり, 境界面上の フーチングコンクリート応力分布を応力成分ごとに $\theta=$ $0^{\circ}, 45^{\circ}, 90^{\circ}, 135^{\circ}, 180^{\circ}$ の各断面について,

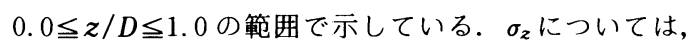

(b) に加えて (e) に, 杭頭頂部の境界面 $(z=l)$ を軸に とって, 境界面およびその延長面上のフーチングコンク リート応力分布を $0.0 \leqq r / D \leqq 0.875$ の範囲で示してい る. 応力値は境界面上の節点応力の平均值で表わし, 各 節点における値を直線でむすんでいる．また, 破線で境

\section{表一1 荷重条件および諸物性値}

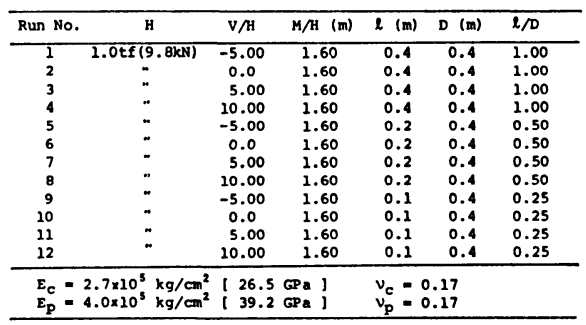

(a)
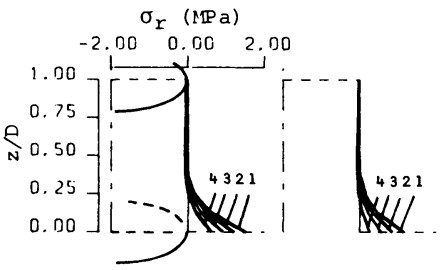
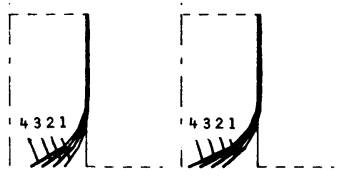

(b)
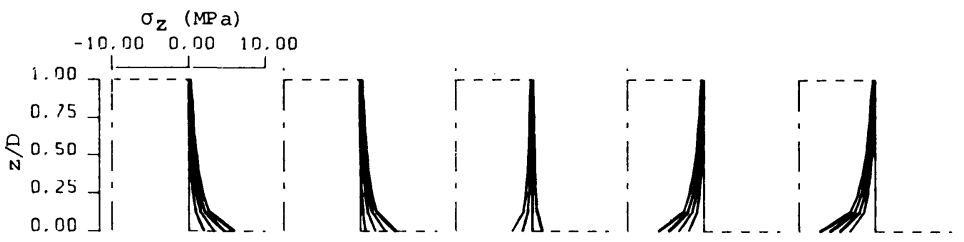

(c)
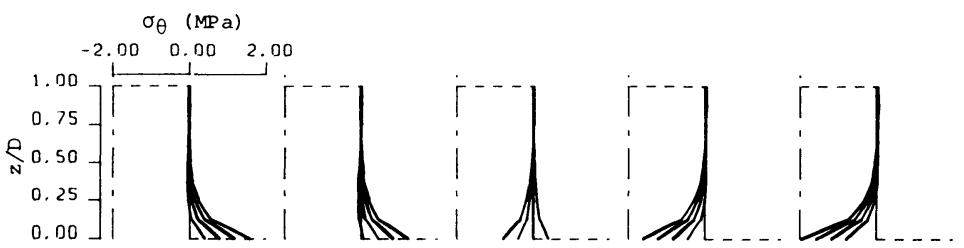

(d)
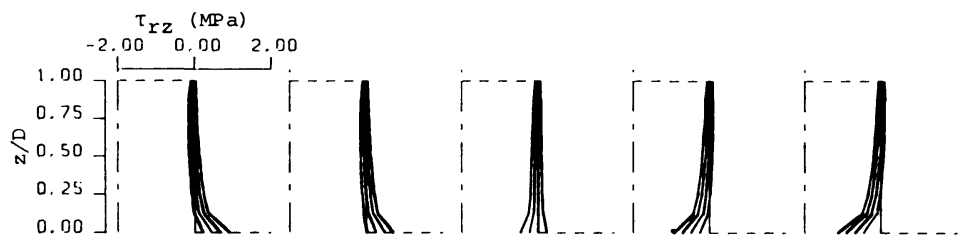

(e)
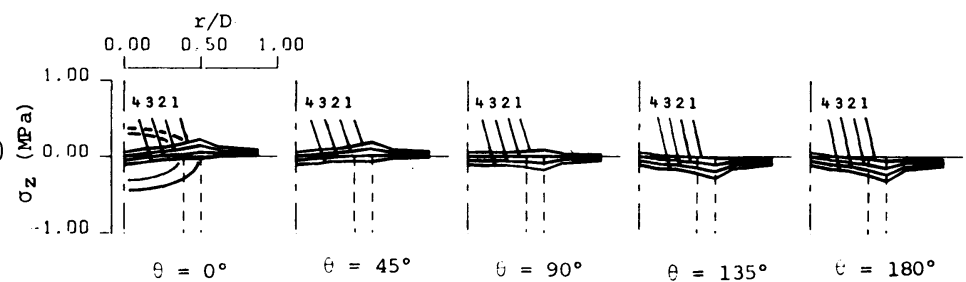

図一4 境界面上のフーチングコンクリート㐫力分布 $(l / D=1.00)$ 
界面およびフーチング下面（(e) では杭内側面の境界面 も）を示し，一点鎖線で回転軸を示している. 図中，(a) および (e) に付した数值は, 表一1 中の Run No. と対 応している. (b)〜 (d) については, (a) にならって対 応をつけられたい. なお, 応力成分のうち, $\tau_{r \theta}, \tau_{z \theta}$ に ついては, 他の応力成分に比較して値が小さいのでここ では省略した。 また，杭側面の境界面では， $\sigma_{z}, \sigma_{\theta}$ は 定義されないが, 境界面上の節点の節点応力として境界 面のごく近傍のいわば極限値として算出される.した がって, 図一4 図一6中の $\sigma_{z}, \sigma_{\theta}$ は境界面のごく近傍 のフーチングコンクリートの応力值として解釈された w.

さて, 各図の (a) をみると, フーチングの下面に近 い $l / D \leqq 0.25$ の領域で急激に応力值が増加し, フーチ
ング下面で最大となる，この傾向は，各図の (b), (c) で示した $\sigma_{z}, \sigma_{\theta}$ に関しても同様である.

さらに, 各図の (a) からは, 軸力 $V$ が増加するにつ れて応力分布が圧縮側へシフトしており, 軸力が $\sigma_{\tau}$ の 分布に影響していることがわかる. 図一4 (a) の $\theta=0^{\circ}$ を例にとれば， $V / H=10.0$ (Run No.4) の場合, $V / H=0.0$ (Run No.2) の場合に比較して約 $60 \%$ の引 張り応力の減少となり, 軸力の $\sigma_{r}$ の分布への影響が無 視し得ない大きさであることがわかる.この, 軸力の増 加に伴う応力分布の圧縮側へのシフトは, $\sigma_{z}, \sigma_{\theta}, \tau_{r z}$ に関しても同様である.

図一4〜図一6で $(\mathrm{a}) \sim(\mathrm{c})$ をおのおの対応させてみる と杭頭埋込み長 $l$ の減少に伴って, 杭頭部全体が大きな 応力の範囲に入ることがわかる. また，lの減少ととも

(a)

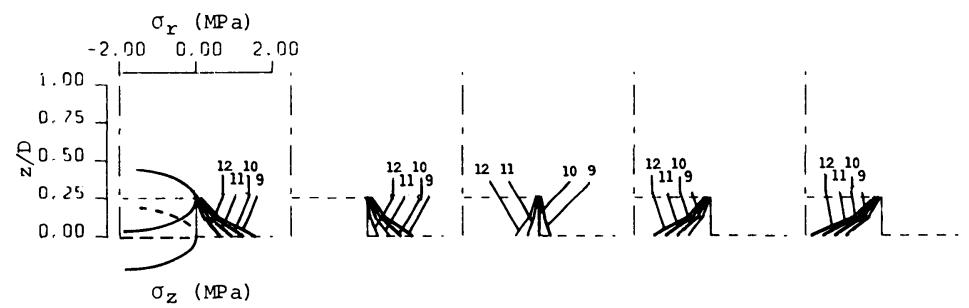

(b)

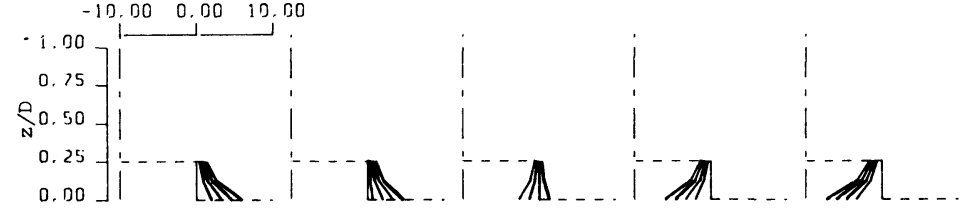

(c)
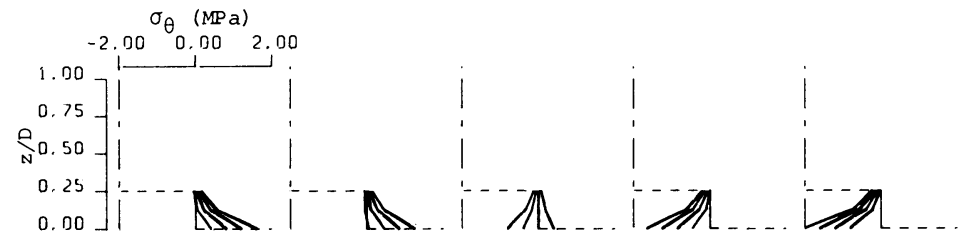

(d)

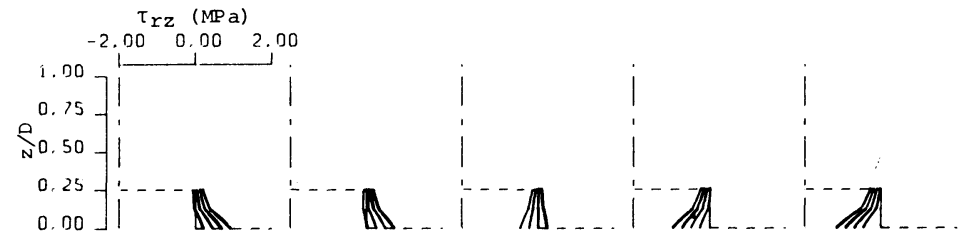

(e)

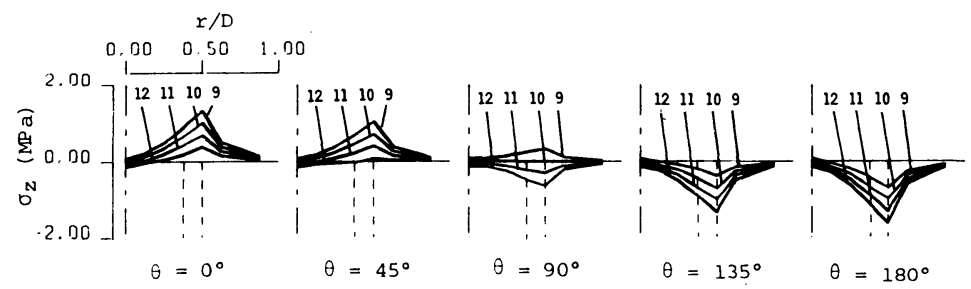

図一5 境界面上のフーチングコンクリート応力分布 $(l / D=0.50)$ 
に, 応力分布が, フーチング下面へ移動していく傾向も みられるが，量的にはわずかである.

これに対して， $\tau_{r z}$ は図一4 (d) ではかなり平坦な分 布をしているが，lの減少とともにフーチング下面近傍 への応力の集中が顥著となる，しかし，值自体は， $\sigma_{r}$ の $1 / 2$ 以下である.

図一4一図一6の (e) をみると, 杭頭頂部におけるフー チングコンクリートの $\sigma_{z}$ の分布は, 杭肉厚部でピーク を有する分布となっており，杭頭にモーメントが作用し た場合には，その傾向をさらに助長していることがわか る.また, $l$ の减少に伴って, $\sigma_{z}$ の值は, 特に杭肉厚部 で急激に増加し，ピーク值で比較すると， $l / D=0.25$ の場合は $l / D=1.00$ の場合も約 5 倍となっている. 図 -4〜図一6で (d) に着目すれば, lの减少とともに杭-
フーチング間の摩擦力が減少することがわかり，このこ とと, 図一4〜図一の (e) を合わせて考えれば, 杭一フー チング間の付着あるいは摩擦が杭頭頂部における $\sigma_{z}$ の 緩和に寄与していることがわかる.

次に, 参考までに, 本解析による応力の值と, 示方書 の応力照查式 (図一1 参照) による応力値との比較を行っ てみる（本解析では杭周面の付着を考慮しているのに対 して, 示方書の応力照査式ではこれを考慮していないの で厳密な意味での比較はできない).

$\sigma_{r}\left(=\sigma_{c h}\right)$ については, 軸力の作用していない図一4 (a), $\theta=0^{\circ}$, Run No. 2 における応力值と比較すれば, 解析値は照査值（図一1 の応力照査式参照）の約 $80 \%$ となっている. しかし，軸力の作用している図-4（a), $\theta=180^{\circ}$, Run No. 4 における応力值と比較すれば, 解

(a)
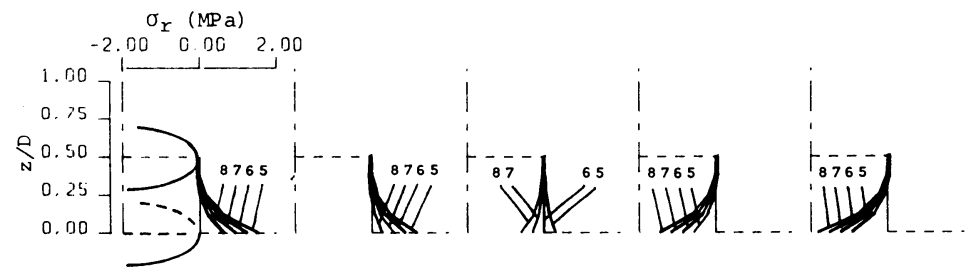

(b)
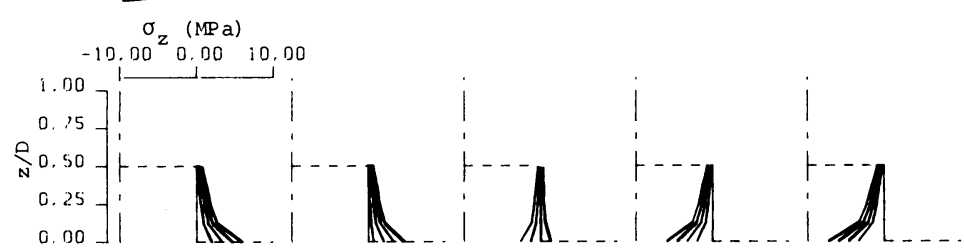

(c)
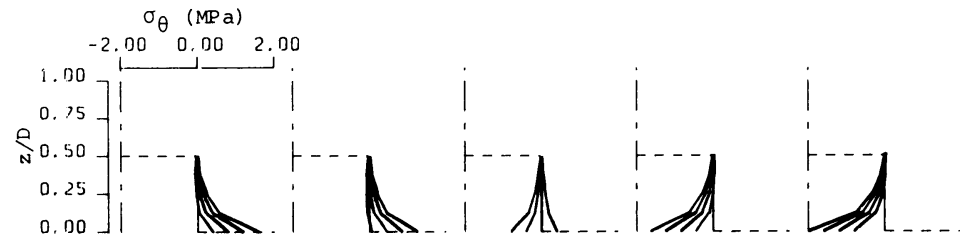

(d)
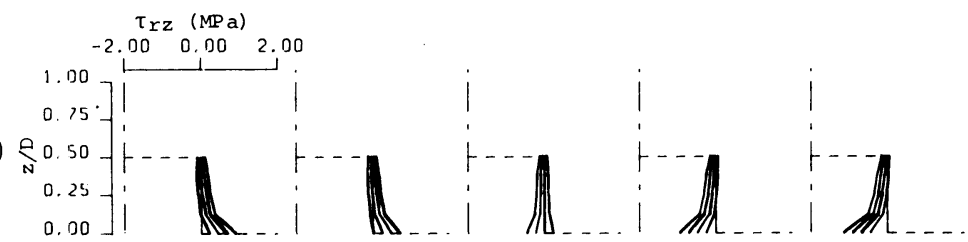

(e)
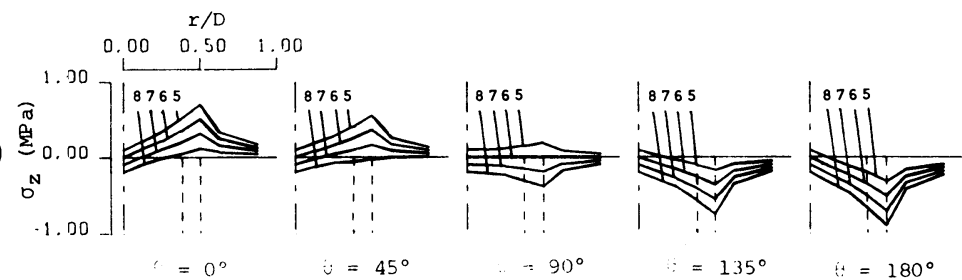

図一6 境界面上のフーチングコンクリート応力分布 $(l / D=0.25)$ 
析値は照査値の約 $120 \%$ となっている（いずれも解析值 はフーチング下面での値). 一方, $\sigma_{z}\left(=\sigma_{c v}\right)$ については, 方法 A 相当の図一4 (e), $\theta=180^{\circ}$, Run No. 4 および 方法 B 相当の図-4 (e), $\theta=180^{\circ}, R u n$ No. 12 との比 較をそれぞれ行えば, それぞれ解析值は照查值の約 $40 \%$, 約 $210 \%$ となっている（いずれも解析值は杭肉厚 部でのピーク値). 杭周面における付着を考慮せず, そ れゆえ安全側の指標であるはずの照査値を, 付着を考慮 した,いわば危険側の解析值が上回る場合があることは, 数値計算の結果とはいえ注目される.

\section{4. 結言}

$\mathrm{PC}$ 杭を例にとって, 杭頭結合部の応力解析を, 有限 要素法を用いて行った. 杭周面での㔀離やすべりを考慮 しない弾性線形解析の結果ではあるが, 得られた結果は 以下のように要約できる.

（1）杭側面のフーチングコンクリートの応力分布 は，フーチング下面近傍に集中している.

（2）軸力は，杭側面の応力分布に大きく影響してい る.

(3) 杭頭頂部の $\sigma_{\boldsymbol{z}}$ は, 杭肉厚部でピークを有する 分布をし，杭頭にモーメントが作用する場合には，その 傾向が助長される.

(4) 杭頭頂部の $\sigma_{z}$ は, 杭-フーチング間の付着およ び摩擦により大きく緩和される.

以上は, 単に数值計算の結果ではあるが, 杭周面の付 着の効果に関しては, 既存の実験結果と傾向の一致を示 しており, 他の解析結果に関してもおおむね妥当な結果 と思われる.

本報告では，杭-フーチング間の付着が保たれる場合 に関する解析を行ったのであるが，示方書では，杭周面 の付着は応力照査に関しては考慮していない.しかしな がら, 杭頭結合部の設計に関しては一部で杭周面の付着 に依存（すなわち付着を考慮）しており ${ }^{11)}$ ，杭周面の付 着の取り扱いに関しては若干の予盾が感じられる. 杭周 面の付着が杭頭結合部の応力分布に与える影響の大きい ことは既存の多くの実験結果の示すところであり, 文献
3 ) では, 杭周面の付着を設計において考慮することの 妥当性を示唆している. したがって, 将来, 杭周面での 付着を考慮した設計を考える場合の資料の一部として, 本報告の内容は有用であろう.

なお, 著者らは, 現在, 杭周面の付着が切れた場合に ついての解析を行っており, 近い将来にその成果を報告 すべく準備中である.

最後に, 本研究における数値計算には, 金沢大学計算 機センター設置の FACOM M-170 F を使用したことを 付記する.

\section{参 考 文 献}

1）道路橋示方書 - 同解説 IV 下部構造編, 日本道路協会, pp. 308 315, 1980 .

2）駒田・岡山：くい頭部とフーチングの結合に関する研究, 道路, pp. 37 41, 1975-6.

3）たとえば，榎並ほか：鋼管杭頭部の支圧及び付着に関す る研究 (その $1 \sim$ そ 6 ), 日本建築学会大会学術講演梗 概集, pp. 2021 2032，1980.

4) 福井ほか：くい頭結合部の耐力に関する模型実験, 土木 学会第 36 回年次学術講演概要集, III-307, 1981.

5）及川ほか：荒川湾岸橋におけるクイ頭部フーチング応力 の検討, 橋梁と基礎, 第 10 巻, 第 3 号, pp. 13 18, 1976.

6）土木研究所資料：杭頭結合条件を考虑した橋梁杭基礎の 設計, No. 1874, 1982 .

7) 近田・小堀：杭頭結合部の FEM を用いた応力解析, 土 木学会中部支部研究発表会講演概要集, I-30，1983-2.

8）黒正ほか：水平力を受ける杭と基礎との結合部に関する 研究 (その 3 ), 日本建築学会大会学術講演梗概集, pp. 2735 2736, 1983-9.

9) Winnicki, L. A. and Zienkiewicz, O.C. : Plastic or visco-plastic behaviour of axisymmetric bodies subjected to non-symmetric loading - semi-analytical finite element solution, Int. Jour. for numerical methods in engineering, Vol. 14, pp. 1399 1412, 1979.

10) Carter J. P. and Booker, J. R. : Consolidation of axisymmetric bodies subjected to non axi-symmetric loading, Int. Jour. for numerical and analytical methods in geomechanics, Vol.7, pp. 273 281, 1983.

11）浅間・足立：くい頭部とフーチングの結合部の設計一道 路局企画課長通達の解説一, 道路, pp. 76 84, 1972-7.

(1983.10.14 • 受付) 